\title{
Ciudad y corregidores: praxis de la integración del oficio regio en el sistema urbano de poder. El concejo de Cuenca durante la fase de instalación de la monarquía isabelina (1474-1483)
}

\author{
José Antonio Jara Fuente ${ }^{1}$ \\ Universidad de Castilla-La Mancha \\ JoseAntonio.Jara@uclm.es
}

RESUMEN: Las medidas de centralización politica emprendidas por los Reyes Católicos tienen en la figura del corregidor uno de sus pilares fundamentales. Su presencia en el mundo urbano persigue su sometimiento a las directrices centralizadoras regias, lo que constituye una injerencia en los espacios de reproducción de las elites locales y explica la oposición mostrada por éstas a su despliegue en las ciudades y los diferentes ritmos experimentados por la imposición de estos oficiales en los diversos entes urbanos, pues no todas las ciudades y villas demostraron similares disponibilidades y capacidades para ejercer esa oposición. En este estudio se busca analizar, desde la cotidianeidad de los procesos de toma de decisiones, el marco de relación política que el concejo de Cuenca llegó a establecer con los agentes de la centralización. Se ha optado por escoger una cronología precisa $y$ relativamente corta, que permite abordar con cierto nivel de detalle el proceso de inserción estable del corregidor y las medidas adoptadas por la ciudad para "gestionar» su presencia y participación en la vida política urbana. Se ha contado para ello con los ricos fondos documentales del Archivo Municipal de Cuenca y del Registro General de Corte.

\footnotetext{
* Este trabajo forma parte del proyecto «Ciudad y nobleza en el tránsito a la Modernidad: autoritarismo regio, pactismo y conflictividad política. Castilla, de Isabel I a las Comunidades» (ref. HAR2017-83542-P), financiado por MICIN/AEI/FEDER, período 2018-2021.

Siglas utilizadas: Archivo General de Simancas, Simancas, Valladolid (AGS), Registro del Sello de Corte (RSC); Archivo Municipal de Cuenca, Cuenca (AMC), Libros de Actas (LLAA).

1 ORCID iD: https://orcid.org/0000-0003-1480-044X 


\section{Palabras clave: Corona de Castilla; Reyes Católicos; Cuenca; corre- gidores; centralización política.}

Cities and their Keepers: the incorporation of royal officers into the urban power system. The city of Cuenca during the consolidation of the Isabelline monarchy in Castile (1474-1483)

ABSTRACT: Keepers of the City or corregidores were one of the fundamental pillars of the centralization policies adopted by the Catholic Monarchs. Their presence in towns aimed to ensure the enforcement of royal centralization directives, thus interfering in the socio-political reproduction spheres of local elites. This helps to explain the opposition of urban elites to the deployment of these officers in their towns, and variations in the speed of imposition of these keepers among diverse urban entities, since not all towns demonstrated similar abilities and skills to exercise that opposition. This paper analyses the political relations framework developed by the city of Cuenca with these centralization agents, focusing on day-today decision-making processes. Our study comprises a precise and relatively short chronology in order to address in some detail the steady process of incorporating these officers, and the measures adopted by towns to «manage» their presence and participation in urban political life. This article has benefited from the rich archival sources of Cuenca Municipal Archive and the Registro General de Corte (Simancas).

\section{Key words: Crown of Castile; Catholic Monarchs; Cuenca; Keepers of the City; Political Centralization.}

CÓMO CITAR ESTE ARTÍCULO / CITATION: Jara Fuente, José Antonio, «Ciudad y corregidores: praxis de la integración del oficio regio en el sistema urbano de poder. El concejo de Cuenca durante la fase de instalación de la monarquía isabelina (1474-1483)», Hispania, 81/268 (Madrid, 2021): 333-363. https://doi.org/10.3989/hispania.2021.009

Aunque experimentando momentos de desaceleración, producto de la incapacidad transitoria para imponer su programa político, el siglo XV en Castilla constituye un período de afirmación de la centralización política regia. Una centralización que utiliza la figura del corregidor como su principal instrumento en el ámbito urbano, «acostumbrando» a éste a aceptar las injerencias regias en la vida local; justificando la presencia de este oficial en la necesidad de apaciguar los conflictos que surgen en ellas prácticamente a lo largo de toda la centuria, enfrentando a diversos sectores de los dominantes - aliados en ocasiones con el común - o a aquellos con los hombres buenos pecheros; y transformando progresivamente esa presencia de una designación ocasional y justificada directamente en aquellos contenciosos en otra más permanente y de una legitimación más dudosa; culminando este proceso en las Cortes de Toledo de 1480, configurando como ordinaria esta plantilla de oficiales. Lejos quedan las reclamaciones de las ciudades exigiendo que el envío de corregidores se 
efectúe a su petición, que se regule a su conveniencia la duración de estos mandatos y se impongan controles sobre su actividad, el juicio de residencia. El énfasis, ahora, se fija en la necesidad de controlar las prórrogas de los mandatos, la idoneidad del oficial y el examen del servicio prestado, más que en discutir la oportunidad del oficio ${ }^{2}$.

Para los Reyes Católicos, la agencia corregimental representa un instrumento perfecto para someter los gobiernos urbanos a sus políticas centralizadoras. Siendo los corregidores «hombres» de los monarcas, ajenos a las ciudades en las que ejercen sus funciones, que deben su promoción a sus vínculos con los reyes, y su éxito, a su capacidad para imponer aquellas políticas, se comprende su identificación con la punta de lanza de la centralización en las ciudades. Para las elites urbanas y especialmente para aquellas que ocupan el corazón de la dominación, ejercer el control sobre los espacios y mecanismos que la articulan en sus ciudades resulta fundamental para su supervivencia como centro de poder. La presencia del corregidor, percibida por esas elites $-\mathrm{y}$ concebida por la monarquía - como un instrumento de supervisión — de control— del sistema urbano, supone una agresión «insoportable» a los fundamentos de la reproducción sociopolítica de esas elites, lo que explica la oposición que ejercen a la presencia de aquellos agentes, en algunos lugares beligerante, incluso violenta, mediante la que se disputa la hegemonía de uno u otro poder ${ }^{3}$.

Sin embargo, esta imagen general no explica adecuadamente la lógica y alcance de la inserción de los oficiales corregimentales en los sistemas urbanos, ni la especificidad de su incorporación en los primeros años de la monarquía isabelina, sometida a una debilidad inicial, producto de la guerra sucesoria, que la forzaría a imponer la recepción de estos agentes mediante mecanismos de negociación - y el recurso a medidas coercitivas - , en una política disenada inicialmente para manifestar el reconocimiento de los agentes de la dominación urbana por parte de la agencia centralizadora, generando una dinámica política a medio camino entre la competencia y la cooperación ${ }^{4}$. El análisis de lo que esa incorporación representó realmente sólo puede hacerse a partir del

${ }^{2}$ Para una presentación general de estos problemas, GONZÁLEZ ALONSO, 1970. BERMÚDEZ AZNAR, 1974. LUNENFELD, 1987. Sobre la normativa que regula la institución, además de los anteriores, PÉREZ PRIEGO, 1997, vol. II: 1169-1178. LOSA CONTRERAS, 1999: 230-231. RAMOS VÁZQUEZ, 2002: 132-133.

${ }^{3}$ Es imposible reseñar aquí el conjunto de publicaciones que, especialmente en las dos últimas décadas, se han dedicado al estudio de los corregidores. Por ello, y aparte de las obras citadas en este artículo, para una revisión bibliográfica de estos estudios en Castilla, véanse RUFO YSERN, 1991: 55-75. GUERRERO NAVARRETE, 1994-1995: 99-124. DIAGO HERNANDO, 2004: 195-223. ASENJO GONZÁLEZ, 2015: 1-28. JARA FUENTE, 2017b: 53-87.

${ }^{4}$ Dinámica que he examinado en JARA FUENTE, 2017b: 53-87. Ver también LUNENFELD, 1987: 4-5 y 34-40. JIMÉNEZ ALCÁZAR, 1994: vol. II, 87-96. GUERRERO NAVARRETE, 2000-2002: 59-102. 
estudio de lo que esas prácticas políticas constituyeron en cada momento en cada concejo. Se trata, como ya planteara Monsalvo Antón ${ }^{5}$, de examinar la cotidianeidad de los procesos de toma de decisiones, dentro y al margen de sus espacios formales de adopción; las prácticas sociopolíticas que allí tienen lugar $\mathrm{y}$, especialmente, los posicionamientos en el interior del sistema urbano de dominación y las relaciones establecidas - dentro y fuera de la agencia urbana - con ocasión de la incorporación al sistema de los agentes corregimentales. Es en la cotidianeidad de la realidad político-relacional que liga a corregidores y ciudades donde se encuentra una explicación más detallada y correcta de esos procesos.

El estudio de caso que proponemos, dedicado al concejo de Cuenca, adapta ese marco de análisis al examen de la forma en que opera la centralización en los primeros años de la monarquía isabelina, desde su entronización hasta el despliegue inicial de las medidas adoptadas en las Cortes de Toledo de 1480, que coincide con el último mandato de su segundo corregidor en Cuenca, Juan Osorio, abarcando así los años 1474 a 1483. A partir de la rica documentación obrante en el Archivo Municipal de la ciudad y del Registro General de Corte (Simancas), se ha desarrollado una estrategia de análisis que, descansando en esa cotidianeidad, privilegia el estudio de las relaciones políticas operadas entre las diversas agencias y actores presentes en el área, extendiendo así el análisis más allá de la figura del corregidor, a otros agentes reales con los que compite funcionalmente; y centrando el examen de lo que supone esa relación en el marco urbano, en las áreas sobre las que el regimiento fue capaz de mantener un control casi absoluto o como mínimo suficiente, así como determinando los instrumentos utilizados por los regidores para sostener su preeminencia en esa cronología. La conclusión, que avanzamos, es que el corregidor, en los años objeto de estudio, no representó en Cuenca un poder contradictorio a los intereses de la elite dominante y pudo ser percibido incluso como un agente cooperador en la preservación de su posición. De esta manera, centralización y poder local autónomo no significaron necesariamente, en esos años, instancias y prácticas políticas de conflicto.

COMPITIENDO POR LA CENTRALIZACIÓN: UNA MULTIPLICIDAD DE PODERES EN EL ENTORNO DE LA CIUDAD

Para el mundo urbano, la presencia del corregidor, como representante de la autoridad central que se quiere hacer patente en la ciudad, no constituye la única ni la principal fuente de preocupaciones en el período inicial de

\footnotetext{
${ }^{5}$ MONSALVO ANTÓN, 1986: 101-167.
} 
consolidación de la autoridad centralizada isabelina, que aquí nos interesa. El contexto político de guerra civil que se experimenta en Castilla hasta 1479, y que afecta de manera particular al área conquense, explica el avance relativamente lento de la efectiva centralización monárquica en este área, cuyos representantes han de competir por el control del espacio político no sólo con la agencia urbana sino con un amplio espectro de linajes de la mediana y alta nobleza del reino presentes, que, rebeldes o leales a los reyes, persiguen sus propios intereses políticos y patrimoniales, lo que les llevaría a actuar al margen o en enfrentamiento directo con la autoridad regia y las áreas urbanas sobre las que aquellos intereses particulares pretendían proyectarse ${ }^{6}$.

\section{La presencia de poderes contradictorios y la eficacia de la función corregimental}

La situación que se experimenta en el área conquense no es sólo producto de la acción autónoma de la nobleza territorial sino, así mismo, consecuencia de la debilidad mostrada por la propia monarquía. Así lo reconoce Enrique IV, el 11 de junio de 1469, en carta dirigida al concejo y al corregidor de Cuenca, en la que, como consecuencia de las alteraciones habidas en el reino, admite haber hecho merced de lugares, términos y jurisdicción del concejo, $\mathrm{y}$, lo que no es menos importante, reconoce que

... yo non pude faser las tales merçedes, nin apartar nin esemir de mi corona real nin de la dicha çibdad logar nin vasallo nin término nin jurisdiçión, a ello entendiendo ser asy conplidero a my seruiçio 7 .

En consecuencia, y asumiendo que los titulares de dichas mercedes ya habrían tomado posesión de sus beneficios, ordenaba al concejo, corregidor y demás oficiales recuperarlos física y simbólicamente, «derribando cualquier forca o mojones que en sennal dello» — del señorío adquirido - hubiera erigido el nuevo señor.

${ }^{6}$ Sobre estos linajes nobles y sobre los conflictos con Cuenca, QUINTANILLA RASO, 1997a: vol. I, 707-736; 1997b: 103-132. GUERRERO NAVARRETE y SÁNCHEZ BENITO, 1994: 138-142. SÁNCHEZ BENITO, 1996: 89-118; 2014: 463-501; 2016: 54-71. JARA FUENTE, 2007: 143-170; 2016: 267-289; 2017a: 327-370; 2018: 114-147.

7 AGS, Cancillería, RSC, leg. 147511-705, fols. 1r-2r.

Las reclamaciones de las ciudades contra estas políticas se suceden a lo largo del siglo: Cortes de 1442 (peticiones 2, 25 y 26), Córdoba, 1455 (petición 5), Salamanca, 1465 (petición 18), Ocaña, 1469 (petición 4), Madrigal, 1476 (peticiones 8 y 86). Véase CORTES, 1882, vols. III y IV. 
En el mismo documento, Enrique IV ponía de manifiesto las profundas contradicciones que venía experimentando la imposición e implementación de la centralización monárquica, al ordenar al concejo, corregidor y autoridades urbanas que no cumplieran ninguna carta $\mathrm{u}$ orden que pudiera otorgar en contrario «commo quier que por ellas se diga que gelo yo mandé de mi propio motuo e çierta çiençia e que cunple a mi seruiçio e a la paçificaçión de mis regnos». En este contexto de alta conflictividad política, el carácter «absoluto» del «propio motuo e çierta çiençia» no sólo se encontraba fuertemente limitado sino que, de la consecuencia lógica que de esas limitaciones cabía concluir, se hacía partícipe activo al corregidor, es decir, al responsable de la implementación de las políticas de centralización en la ciudad, a quien ahora se corresponsabilizaba, junto a las autoridades urbanas, del «desmantelamiento» del fundamento teórico de aquellas prácticas ${ }^{8}$. Incluso si aquel sólo tenía un alcance teórico y/o coyuntural, el solo reconocimiento de esas restricciones constitucionales podía tener consecuencias no deseadas para la autoridad regia, como ilustra la situación que vive Lope Vázquez de Acuña, conde de Buendía y miembro del partido rebelde hasta su reintegración en el servicio de los reyes. En octubre de 1477, los monarcas se dirigen al concejo de Huete y a la Hermandad de la provincia conquense ordenando respetar el seguro que otorgaban a Lope Vázquez, su mujer e hijos, allegados y bienes. Lope Vázquez, que conservaba su condición de vasallo de los reyes y de miembro del Consejo Real, había solicitado a los monarcas que le otorgaran su guarda y le dieran carta de seguro pues temía que vecinos de Huete y de las ciudades y villas comarcanas le tuvieran enemistad y le causaran daños, por haber estado en deservicio de los reyes. Ello no obstante el perdón concedido por los monarcas el 13 de febrero del mismo año, que se extendía a todas las muertes, crímenes, robos y demás delitos cometidos por Lope Vázquez y su gente desde la muerte de Enrique IV, lo que otorgaban por «nuestro propio motuo e çierta çiençia e poderío real absoluto»". Lope Vázquez de Acuña, uno de los grandes responsables de las agresiones sufridas por los concejos y tierras de Cuenca y Huete — no sólo con ocasión de la guerra sucesoria-, se veía en esta tesitura necesitado de la protección regia frente a las posibles represalias que contra él pudieran intentar estos concejos y sus vecinos.

La posibilidad de estas conductas manifestaba un cierto grado de autonomía política del concejo, expresada en la ausencia de toda referencia a la intervención de otras autoridades implicadas. Algo similar sucederá con los contenciosos experimentados en el último trimestre de 1476 por el concejo con el comendador Alonso de Iniesta, señor de Valera de Yuso, El Olmeda y Solera. Como Lope Vázquez, Alonso de Iniesta también se vio forzado a reclamar la protección de la

\footnotetext{
${ }^{8}$ Sobre la noción de monarquía absoluta, NIETO SORIA, 2005: 73-92; 2010: 15-55. MORÁN MARTÍN, 2005: 93-114. CARRASCO MANCHADO, 2011: 613-652.

9 AGS, Cancillería, RSC, leg. 147710-7, fols. 1r-2v; leg. 147710-140, fols. 1r-1v; leg. $147702-$ 109, fols. 1r-2v.
} 
corona frente a las decisiones adoptadas por la ciudad en materia de fiscalidad. Dichos lugares habían pertenecido a Cuenca y tributado con el resto de sus aldeas en la fiscalidad regia descargada sobre el concejo y su tierra, estando sometidos a los acuerdos adoptados por el concejo en relación con la distribución de esa fiscalidad entre los distintos concejos aldeanos. Como se recoge en carta de Isabel I a Cuenca y a los arrendadores y recaudadores del pedido del obispado conquense, de 22 de agosto de 1476 - presentada ante el concejo el 24 de septiembre-, el comendador protestaba porque el concejo había sobrevalorado la capacidad contributiva de sus aldeas, imponiéndoles una participación mayor, a la que entendía corresponderles, en el pago del pedido. Ante el apoyo prestado por la reina al comendador, prohibiendo «cargar de más» a sus concejos, Cuenca reaccionaría, el mismo 24 de septiembre, denunciando la existencia de un portazgo ilegal en Valera de Yuso, y al día siguiente, elevando el envite en un doble sentido, denunciando: primero, la nulidad de la carta de la reina, «por quanto la relaçión en la dicha carta contenida fue e es contraria e repunante a sy mesma [y] la dicha carta fue subrretiçia e obrretiçia», $\mathrm{y}$, segundo, la propia condición de señorío de Valera de Yuso, que se rechaza ${ }^{10}$.

No sucede lo mismo en otros casos, en los que la sola autoridad del concejo es incapaz de imponerse, forzando la llamada a la intervención de representantes de la agencia regia e, incluso, de otros agentes cuya relación con aquella agencia se formaliza a través de registros conexos a sus canales propios y directos. Es el caso del conflicto que sostiene la ciudad con el prior de Belmonte en 1477. En este caso, el bachiller Juan de Paz, corregidor de Cuenca, habría intervenido en beneficio de la ciudad, realizando una pesquisa sobre aquel. Como consecuencia de su alineación con los intereses de Cuenca, el prior denunciaría la parcialidad del corregidor - real o producto de su argumentación jurídica-, forzando a la reina a incorporar a la resolución del conflicto a otro oficial, un pesquisidor, cuyos trabajos también fueron objeto de la oposición del prior ${ }^{11}$.

Algo similar sucede en el caso de Pero Carrillo de Albornoz, señor de Torralba y Beteta, y de Pedro de Barrientos. Respecto de aquel, sabemos de unos primeros conflictos de carácter judicial surgidos entre él y el concejo de Cuenca por una ejecución ordenada, hacia agosto de 1476, por la justicia de la ciudad, a petición del comendador de Huélamo, por un crédito que ostentaba contra aquel. En esta ocasión, el enfrentamiento entre las partes tendría un

${ }_{10}$ AMC, LLAA, leg. 200, exp. 2, fols. 9v-10r y 11r y 13-14v.

Reclamación similar presentaron las aldeas de La Parrilla y Belmontejo, señorío del marqués de Villena, en febrero de 1476, con el mismo resultado: la imposición de la decisión de la ciudad. El 26 de junio, dichos concejos y los de Valera de Yuso, Solera y El Olmeda, solicitaban a Cuenca la confirmación de una iguala sobre la distribución de la «base imponible» que les correspondía. En la sesión estuvo presente el guarda mayor, y la solicitud fue confirmada al ajustarse a lo que les era aplicable. AMC, LLAA, leg. 200, exp. 2, fols. 20r y 21r, y 7r-8r.

11 AGS, Cancillería, RSC, leg. 147706-260, fols. 1r-v. 
alcance sencillamente bilateral — con acciones de represalia económica emprendidas por Pero Carrillo-, sin la presencia o reclamación de terceros agentes $^{12}$. Por otro lado, ambos señores tenían ocupadas las fortalezas conquenses de Alcantud y Cañizares, el primero, y de Enguídanos, el segundo. Ni la ciudad ni el representante regio en el área, bachiller y corregidor Juan de Paz, habían conseguido recuperarlas, forzando, una vez más, la intervención de la reina. El 15 de septiembre de 1477, ésta ordenaba a los usurpadores la entrega de las fortalezas al bachiller y a un nuevo personaje enviado al área en apoyo de la autoridad regia, el doctor de Briviesca, Pero Sánchez de Frías, del Consejo Real, comisario y juez de términos; además, apoderaba a ambos para reclamar el auxilio de los concejos de Cuenca, Huete, Molina y Moya y de sus hermandades, para «las tomar por fuerça de armas» en el caso de que no las entregaran voluntariamente, pues ambos eran señores poderosos en el área ${ }^{13}$. El comisario dictaría sentencias de restitución de las fortalezas y de otros términos entrados por estos y otros señores que, dos años más tarde, en noviembre de 1479, seguían sin alcanzar cumplida ejecución ni por el juez comisario ni por los corregidores de la ciudad. En esa fecha, Fernando V ordenaba al corregidor Juan Osorio ejecutarlas sin otra dilación ${ }^{14}$. El 20 de mayo de 1480, los reyes denunciaban aún la falta de ejecución de aquellas sentencias, designando para hacerlo no al corregidor de Cuenca sino a dos oficiales ajenos a esa instancia de representación regia, Cristobalillo de Aguilar, caballero de la casa de los reyes, y Diego Medarrano, caballero y capitán, designados meros ejecutores para el cumplimiento de dichas sentencias ${ }^{15}$.

Como muestran los casos examinados, la presencia del corregidor e, incluso, su buena voluntad hacia la institución urbana en la que había de desempeñar su oficio no aseguraban un ejercicio eficaz de sus funciones. Esta incapacidad no es específica de Cuenca, pues se constata en otros concejos, incluso más allá de $1480^{16}$.

En Cuenca resulta especialmente llamativa la incorporación del guarda mayor de la ciudad, Juan Hurtado de Mendoza, al desempeño de unas funciones que, de otra manera, corresponderían al corregidor. Aproximadamente entre 1474 y 1476-77, los reyes renunciarán a designar corregidor en Cuenca, optando por hacer descansar el peso de su autoridad en este personaje, uno de los más destacados entre la nobleza territorial y dotado de suficiente ascendiente en la ciudad, derivado no sólo del oficio que sirve en ella sino de las relaciones personales

12 AMC, LLAA, leg. 200, exp. 2, fols. 7r-9r.

13 AGS, Cancillería, RSC, leg. 147709-492, fols. 1r-2r; leg. 147809-39, fols. 1r-v.

Para la pesquisa de Pero Sánchez de Frías, QUINTANILLA RASO, 1997b: 103-132.

${ }_{14}$ AGS, Cancillería, RSC, leg. 147911-94, fols. 1r-2r.

15 AGS, Cancillería, RSC, leg. 148005-244, fols. 1r-2v; leg. 148006-39, fols. 1r-2v.

16 MEMBRADO, 2014: 67-84. MONSALVO ANTÓN, 2010a: 115-190. DIAGO HERNANDO, 1993: 47. RAMOS VÁZQUEZ, 2002: 232-243. LOSA CONTRERAS, 1999: 244246. LUNENFELD, 1987: 111-114. 
construidas con miembros de su colectivo dominante. No se trata de una situación excepcional pues en otros concejos la monarquía renunciaría a la designación de corregidor, apoyándose bien en un linaje principal —o viéndose forzada a admitir la realidad del superior poder ejercido por éste en la localidad, como sucede con los duques del Infantado en la ciudad alcarreña-, bien en el conjunto de la ciudad, como sucede en Alcaraz, donde, en la lucha contra el marqués de Villena, parecía razonable renunciar al nombramiento de corregidor para asegurarse la fidelidad alcaraceña ${ }^{17}$. En Cuenca, por dos cartas patentes otorgadas por Isabel I —el 22 de diciembre de 1475 y el 27 de junio de 1476-, sabemos que, con motivo de la participación en el bando rebelde del comendador Alonso de Iniesta, la reina había ordenado a Juan Hurtado de Mendoza y al concejo conquense tomarle los lugares de Valera de Yuso - con su muela-, El Olmeda y Solera, derribar la citada muela y dejar los bienes en secuestro en manos de Juan Hurtado $^{18}$. En dichas cartas, la reina anulaba su decisión previa y ordenaba restituir los lugares al comendador. Se necesitarían varias órdenes para hacer cumplir su mandato a unos recalcitrantes concejo y Mendoza. Finalmente, el 6 de agosto de 1476, en Valera de Yuso, Rodrigo de Torres, regidor de Cuenca, escenificaba la restitución del lugar al comendador, pero no en nombre de la ciudad, como su oficio podría dar a entender, sino de Juan Hurtado, en cuyo nombre actuaba en su condición de criado del señor de Cañete ${ }^{19}$. Ese mismo año, el 22 de enero, tenía lugar una reunión de urgencia en las casas palacio de Juan Hurtado, para informar sobre los movimientos de gentes de armas en torno a la Torre del Aceite, ocupada por mosén Juan de la Panda, uno de los nobles «salteadores» que venían aprovechando los estados de desorden para depredar el territorio comarcano y asaltar a los caminantes ${ }^{20}$. La reunión no resulta extraña en un contexto en el que no sólo el concejo solicita la colaboración del guarda mayor en la defensa de la ciudad, sino que es la propia monarquía la que hace descansar en aquel parte de su esfuerzo bélico en la región. Por carta de 22 de febrero de 1476, sabemos que la reina había ordenado a don Pedro Carrillo de Mendoza, conde de Priego, a Juan Hurtado de Mendoza, guarda mayor de Cuenca y consejero real, y a Honorato de Mendoza, su hijo y montero mayor, hacer la guerra a don Diego López Pacheco, marqués de Villena, a Lope Vázquez de Acuña «e los otros sus sec[u] açes [...] en la conpannía del nuestro aduersario de Portogal»; apoderándolos para reclamar la ayuda militar necesaria a los concejos comarcanos, y para tomar

17 ORTEGA CERVIGÓN, 2009: 703-721. JARA FUENTE, 2004: 139-175. LÓPEZ VILLALBA, 2009: 153-184. PRETEL MARÍN, 1978: 165-170 y 174-176. LUNENFELD, 1987: 49-51.

18 AMC, LLAA, leg. 200, exp. 2, fols. 33r-35r.

19 AMC, LLAA, leg. 200, exp. 2, fols. 3r-v y 35r-36v (reiterando los mandamientos de restitución).

20 AMC, LLAA, leg. 200, exp. 2, fols. 8r-v. 
en nombre de los reyes los lugares rebeldes, anular los juramentos y pleito-homenajes dados por los vecinos y oficiales a sus señores, y recibir sus juramentos, pleito-homenajes y seguridades de permanecer en servicio de los monarcas ${ }^{21}$. Así, a lo largo de estos años, buena parte de la acción política en la ciudad descansó en la cooperación entre guarda mayor y regidores en una multiplicidad de ámbitos de decisión de relevancia para el concejo, como se refleja en la tabla I, que no incluye aquellas acciones examinadas en el texto.

TABLa I. Presencia del guarda mayor en el proceso político-decisional (1476)

\begin{tabular}{|c|c|c|}
\hline Fecha & Participantes & Contenido de la acción \\
\hline 1476 , enero, 15 & Guarda mayor & $\begin{array}{l}\text { Como capitán de la reina, ordena que los vecinos estén } \\
\text { prestos para ser llamados a la milicia. }\end{array}$ \\
\hline 1476, marzo, 17 & regón & $\begin{array}{l}\text { Ordenando a caballeros y peones estar dispuestos para } \\
\text { ser llamados por el guarda mayor para acudir al cerco } \\
\text { de Madrid. }\end{array}$ \\
\hline 1476, abril, 3 & Gua & $\begin{array}{l}\text { Por poder de los reyes, ordena que acudan los vecinos } \\
\text { y moradores a hacer alarde con todas sus armas, en la } \\
\text { mañana siguiente. }\end{array}$ \\
\hline 1476,1 & $\begin{array}{l}\text { Justicia, } \\
\text { regidores y } \\
\text { teniente del } \\
\text { guarda mayor }\end{array}$ & $\begin{array}{l}\text { Carta de los reyes reiterando la orden de recibir a Juan } \\
\text { de Alcalá como voz y voto de regidor. Alcaldes, } \\
\text { alguacil y teniente remiten el recibimiento a lo que } \\
\text { disponga el guarda mayor. }\end{array}$ \\
\hline $1476, \mathrm{j}$ & $\begin{array}{l}\text { y } \\
\text { del } \\
\text { aayor }\end{array}$ & $\begin{array}{l}\text { Carta a la corte, oponiéndose al encabezamiento de la } \\
\text { ciudad, de muros adentro, en el pedido y monedas de } \\
1475 \text {. }\end{array}$ \\
\hline $1476, \mathrm{j}$ & $\begin{array}{l}\text { Gua } \\
\text { y re }\end{array}$ & $\begin{array}{l}\text { La aldea de La Parrilla solicita que se apruebe la iguala } \\
\text { que, en materia de posterías, ha hecho con Valera de } \\
\text { Yuso, El Olmeda, y Belmontejo. La confirman. }\end{array}$ \\
\hline $1476, \mathrm{a}$ & $\begin{array}{l}\text { ayor } \\
\text { s }\end{array}$ & $\begin{array}{l}\text { Designación de peones } \mathrm{p} \\
\text { reina Juan Osorio en la }\end{array}$ \\
\hline $1476, a$ & $\begin{array}{l}\text { Guarda } \\
\text { y regido }\end{array}$ & $\begin{array}{l}\text { Orden a los caballeros armados y guisados de caballo } \\
\text { de acompañar al capitán de la reina Juan Osorio en la } \\
\text { campaña sobre Huete. }\end{array}$ \\
\hline $1476, \mathrm{a}$ & $\begin{array}{l}\text { Guarda mayor } \\
\text { y regidores }\end{array}$ & $\begin{array}{l}\text { Promulgación de nueva ordenanza del oficio de } \\
\text { almotazanía (uno de los catorce oficios del fuero, base } \\
\text { del sistema de participación política en la ciudad). }\end{array}$ \\
\hline 1476, agosto, 4 & $\begin{array}{l}\text { Regidores y } \\
\text { guarda mayor }\end{array}$ & $\begin{array}{l}\text { Acatan la orden de la reina de derribar la muela de Valera } \\
\text { de Yuso, y requieren al guarda mayor para que la ejecute. }\end{array}$ \\
\hline
\end{tabular}

Fuentes: AMC, LLAA. Elaboración propia.

${ }^{21}$ AGS, Cancillería, RSC, leg. 147602-86, fols. 1r-2v. 
Todavía en agosto de 1477, habiendo ya corregidor en la ciudad, los reyes encabezan sus misivas:

... a vos, Juan Furtado de Mendoça, nuestro vasallo e del nuestro Consejo e nuestro guarda mayor de la noble e leal çibdad de Cuenca, e a vos el conçejo, corregidor, allcaldes, alguasil, regidores, caualleros, escuderos, ofiçiales e omnes buenos de la dicha çibdad de Cuenca ${ }^{22}$.

Nótese la jerarquía que se establece en el tratamiento de los distintos actores: primero, el guarda mayor, luego el concejo - en cuanto que agencia-, y sólo tras ellos el corregidor. Una jerarquía que se reitera en la correspondencia que se envía a Cuenca durante ese año de 1477, en la que el primer y segundo lugar pueden variar, alternándose los lugares entre guarda mayor y concejo, pero correspondiendo siempre la posición final al corregidor. Esto resulta especialmente llamativo en el caso del control de ciertos desórdenes que se denuncian en la urbe, en la que algunas gentes «se juntan algunas veces para asonadas, de lo qual todo a nos podría redundar deseruiçio e en la dicha çibdad e su tierra grande danno», según le recuerdan los reyes al bachiller y corregidor Juan de Paz, el 27 de noviembre, reiterándole la orden de controlar esos movimientos, dada en anteriores cartas. Lo cierto es que, con tal fin, el 15 de septiembre, Isabel I se había dirigido exclusivamente a Juan Hurtado, su vasallo, del Consejo y su guarda mayor de Cuenca, y a los regidores para informarles de que para «la buena guarda e conseruaçión e pro e bien común e pas e sosyego desa çibdad», había acordado que las llaves de las puertas de Huete y San Pedro se entregaran al corregidor. La carta no se dirige al guarda, concejo y corregidor sino que, reconociendo implícitamente dónde residía el verdadero poder político en la ciudad, se envía al guarda mayor y a los regidores, sin mención a otros oficiales concejiles, sin inclusión del corregidor y sus oficiales reales, aunque, ante su incumplimiento, la reiteración del mandato, el 26 de noviembre, sí incorpora al corregidor, una vez más en tercer lugar, tras el concejo y el guarda mayor. Lo mismo sucede el 15 de septiembre, cuando la reina recuerda al concejo, guarda mayor, justicia, regidores - y demás elementos de la receptoría epistolar urbana- que ha ordenado entregarle las cuentas al corregidor, para su examen y, ante su incumplimiento, reitera el mandato. Tampoco aquí se incluye en la cláusula de receptoría de la misiva al corregidor y no cabe interpretar que pudiera estar tácitamente recogido bajo la referencia a la «justicia», pues la presencia de corregidor siempre se hace constar expresamente ${ }^{23}$.

${ }^{22}$ AGS, Cancillería, RSC, leg. 147708.432-2, fols. 1r-v.

23 AGS, Cancillería, RSC, leg. 147711-374, fols. 1r-v; leg. 147709-494, fols. 1r-v; leg. 147711-368, fols. 1r-v; leg. 147709-585, fols. 1r-v. 
La preeminencia política del guarda mayor se proyecta, así pues, más allá de ese horizonte sin corregidor que fijábamos en 1476, pues incluso en presencia de este oficial regio, la primacía de Juan Hurtado - y también de la ciudad y sus regidores - sobre el corregidor parece clara. Tan es así que el 21 de febrero de 1478, Isabel I se dirigía al bachiller y corregidor Juan de Paz para anular la orden que le había dado de reclamar las llaves de dos puertas de la ciudad presumiblemente las citadas de Huete y San Pedro - a Juan Hurtado, quien se había negado a entregárselas en su momento y había recurrido ante los reyes, decidiendo ahora éstos que resultaba útil a su servicio que el guarda mayor, y no el corregidor, retuviera el control de esos espacios ${ }^{24}$. El estado de «desapoderamiento» en el que quedaba el corregidor como consecuencia de ello, viendo su autoridad anulada por el guarda mayor y la ciudad, parece evidente. Una sensación que se acentúa al considerar cómo los reyes incorporan a Honorato de Mendoza, hijo del guarda mayor, a ese proyecto de reconocimiento de primacía política. El 4 de febrero de 1475, Isabel I hacía merced a Honorato de Mendoza del oficio de montero mayor, en las mismas condiciones en que lo disfrutara su abuelo, Diego Hurtado de Mendoza; y el 26 de abril, los reyes confirmaban el privilegio de renuncia del oficio de guarda mayor en su persona para cuando falleciera su padre ${ }^{25}$. La nueva condición adquirida por Honorato de Mendoza se hace patente con ocasión del secuestro de los bienes del comendador Alonso de Iniesta, que la reina habría distribuido como merced entre el concejo de Cuenca, Juan Hurtado y su hijo Honorato - según sabemos por cartas patente de 22 de diciembre de 1475 y 27 de junio de 1476-; y al encomendarle, el 22 de febrero de 1476, la guerra contra los rebeldes junto a su padre y el conde de Priego ${ }^{26}$.

\section{Una multiplicidad de agentes vinculados a la centralización política}

La institución corregimental competía en el área conquense con otros agentes de la autoridad regia, lo que en muchos casos suponía, más que un apoyo, una detracción de autoridad y funciones. Ésta podía mostrarse de forma absoluta, eliminando la necesidad de nombrar corregidor al optar los reyes, al menos en esta fase inicial de la guerra civil sucesoria, por apoyarse en personajes bien situados en el espacio político a intervenir. Es lo que sucede en febrero de 1476, al encomendarse la defensa de este sector a Pedro Carrillo y a los Mendoza y, específicamente, a Juan Hurtado en el caso

24 AGS, Cancillería, RSC, leg. 147802-105, fols. 1r-v.

25 AGS, Cancillería, RSC, leg. 147502.128, fols. 1r-2r; leg. 147504.432, fols. 1r-v.

${ }_{26}$ AMC, LLAA, leg. 200, exp. 2, fols. 33r-35r. AGS, Cancillería, RSC, leg. 147602-86, fols. $1 \mathrm{r}-2 \mathrm{v}$. 
concreto de Cuenca, donde actúa como capitán mayor. Y el 23 de mayo, cuando los reyes encomiendan el desarrollo de la guerra en la región al maestre de Santiago don Rodrigo Manrique, quien solicita el apoyo militar del concejo el 2 de abril, para acudir en auxilio del cerco de Madrid, y, nuevamente, el 31 de mayo, para asistirle en la recuperación de la villa maestral de Uclés; o el 13 de junio, cuando extienden un mandato similar a favor del capitán Juan Osorio, a quien se ha encomendado la toma de Huete, para lo que solicitará tropas de Cuenca el 2 de agosto ${ }^{27}$.

La concurrencia de autoridades alcanzaba, así mismo, a aquellos espacios directamente comunicados con el área de proyección del corregimiento que, aunque situados en la periferia de éste, forzaban una permanente necesidad de comunicación entre el corregidor y estos oficiales, limitando la capacidad de acción del primero al quedar sometida a las necesidades, y autoridad, de los segundos. Así sucede tan tarde como en enero de 1480, cuando los reyes ordenan a los concejos, corregidores y asistentes de Cuenca, Huete y demás ciudades, villas y lugares del sector, prestar su apoyo al mariscal Per Afán de Ribera para tomar la posesión de las fortalezas del obispado conquense. Cuatro años antes, el 24 de febrero de 1476 en ausencia de corregidor-, los reyes habían apoderado a don Diego Hurtado de Mendoza, duque del Infantado, para reclamar toda la ayuda que precisara para acometer la toma de la villa de Madrid, lo que permitirá al duque exigir el apoyo militar de Cuenca el 17 de marzo, cuando reclama tropas para continuar con el cerco del alcázar madrileño; y el 25 de junio, al demandar dinero para el pago de ciertas lanzas ${ }^{28}$.

De esta manera, la corona acude a otros colabores para la ejecución de actividades que «naturalmente» habrían correspondido al corregidor o que se hacían necesarias debido a la incapacidad mostrada por este oficial en el desempeño de sus funciones, como se recoge en la tabla II.

27 AGS, Cancillería, RSC, leg. 147602-86, fols. 1r-2v. AMC, LLAA, leg. 200, exp. 2, fols. 3r-4r; leg. 200, exp. 1, fol. 32r-v; leg. 200, exp. 2, fols. 34v-35r; leg. 200, exp. 2, fols. $48 \mathrm{v}-51 \mathrm{r}$.

28 AGS, Cancillería, RSC, leg. 148001-115, fols. 1r-v. AMC, LLAA, leg. 200, exp. 2, fols. $27 \mathrm{v}-28$ r; leg. 200 , exp. 2, fols. $18 \mathrm{r}-\mathrm{v}$ y $23 \mathrm{r}-26 \mathrm{r}$. 
TABLA II. Agentes complementarios de la centralización

\begin{tabular}{|c|c|c|}
\hline Fecha & Actor & Contenido de la acción \\
\hline 1477, marzo, 5 & $\begin{array}{l}\text { Juan Hurtado de Mendoza, } \\
\text { guarda mayor de Cuenca; } \\
\text { Andrés de Cabrera, } \\
\text { mayordomo de los reyes; y } \\
\text { bachiller Juan de Paz }\end{array}$ & $\begin{array}{l}\text { Pesquisidores en un conflicto entre los } \\
\text { regidores y los cabildos de Caballeros } \\
\text { y escuderos y de Guisados de Caballo. }\end{array}$ \\
\hline 1477, marzo, 28 & \begin{tabular}{|lcc}
$\begin{array}{l}\text { Mosén } \\
\text { Alarcón, }\end{array}$ & Alonso & vecino \\
Cuenca & de \\
\end{tabular} & $\begin{array}{l}\text { Designado árbitro por los reyes en un } \\
\text { pleito sobre prendas de ganado entre } \\
\text { dos particulares. }\end{array}$ \\
\hline $\begin{array}{l}1477, \\
\text { septiembre, } 11\end{array}$ & Gerónimo de Valdivieso & $\begin{array}{l}\text { Juez-pesquisidor, quizás también } \\
\text { enviado para realizar la residencia del } \\
\text { corregidor Juan de Paz. }\end{array}$ \\
\hline $\begin{array}{l}1477, \\
\text { septiembre, } 15\end{array}$ & $\begin{array}{l}\text { Doctor de Briviesca, Pero } \\
\text { Sánchez de Frías }\end{array}$ & $\begin{array}{l}\text { Comisarioy juez de términos, designado } \\
\text { en colaboración con el bachiller y } \\
\text { corregidor Juan de Paz para restituir a } \\
\text { Cuenca sus términos entrados. }\end{array}$ \\
\hline 1478 , agosto, 26 & Gerónimo de Valdivieso & $\begin{array}{l}\text { Vasallo de los reyes, pesquisidor } \\
\text { enviado a investigar los conflictos en } \\
\text { la ciudad. Medida de su gravedad es la } \\
\text { duración de la pesquisa, } 45 \text { días. }\end{array}$ \\
\hline $\begin{array}{l}\text { 1479, mayo, } 25 / \\
\text { junio, } 12 / \\
\text { agosto, } 12\end{array}$ & Capitanes reales & $\begin{array}{l}\text { Cuenca protesta ante los reyes porque los } \\
\text { capitanes reales en su sectorno se enfrentan } \\
\text { a las tropas del marqués de Villena. }\end{array}$ \\
\hline 1480, marzo, 11 & Cueva & $\begin{array}{l}\text { Guarda y vasallo de los reyes, } \\
\text { pesquisidor en un conflicto de } \\
\text { términos entre el concejo de Cuenca y } \\
\text { la villa de Priego. }\end{array}$ \\
\hline 1480, mayo, 20 & $\begin{array}{l}\text { Cristobalillo de Aguilar y } \\
\text { Diego Medarrano }\end{array}$ & $\begin{array}{l}\text { Meros ejecutores de las sentencias de } \\
\text { restitución de términos dictadas por el } \\
\text { doctor de Briviesca. }\end{array}$ \\
\hline 1480, mayo, 27 & Cristóbal de Medina & $\begin{array}{l}\text { Capitán del rey (parece que desplegado } \\
\text { en apoyo de ejecutores fiscales). }\end{array}$ \\
\hline 1480 , julio, 25 & $\begin{array}{l}\text { Pero Ruiz de Alarcón y } \\
\text { Sancho del Campo }\end{array}$ & $\begin{array}{l}\text { Capitán real y contino comensal, } \\
\text { respectivamente, designados para } \\
\text { restituir las fortalezas y términos } \\
\text { entrados a Cuenca. }\end{array}$ \\
\hline $\begin{array}{l}1480, \\
\text { noviembre, } 21\end{array}$ & Sancho del Campo & $\begin{array}{l}\text { Contino comensal, vasallo y capitán del } \\
\text { rey, mero ejecutor de las sentencias de } \\
\text { restitución de términos dictadas por el } \\
\text { doctor de Briviesca y aún no ejecutadas. }\end{array}$ \\
\hline
\end{tabular}

Fuentes: AMC, LLAA y AGS, Cancillería, RSC. Elaboración propia. 
La referencia a la presencia de estas autoridades tanto en la ciudad como en su jurisdicción ilustra las dificultades que podían encontrar los corregidores en el ejercicio de sus funciones, como vemos suceder a comienzos del siglo XVI en Logroño, Calahorra y Alfaro, cuyo corregidor sufre la superioridad política del capitán de la frontera de Navarra; en Alcaraz, con el capitán mayor de la frontera Pedro Manrique en 1477; con el corregidor de Asturias y León en su relación con el adelantado mayor de León y sus alcaldes mayores; o en Jaén, donde las funciones de «policía-orden público» del corregidor quedan anuladas por el alguacil mayor, oficio que aquí aquel no suspende. Es así que la sola existencia de otros oficiales actuando en su espacio de intervención suponía no sólo una limitación oficial de sus funciones, en la medida en que venía sancionada por el monarca y no era producto de un conflicto de «reconocimiento» con los poderes locales; sino también una detracción tácita de autoridad que transforma a éste en un canal secundario de poder en beneficio de otros agentes políticos mejor posicionados en el interior del sistema urbano y en su conexión con la agencia regia. Así sucede en Cuenca a lo largo de los primeros años del reinado de Isabel I, al privilegiarse por reyes y ciudad el recurso al linaje Hurtado de Mendoza, incluso en presencia de corregidor ${ }^{29}$.

Así mismo, el constante nombramiento por parte de la monarquía de pesquisidores, meros ejecutores o capitanes de guerra dotados de funciones parajurisdiccionales para la ocasión - como ocurre con Pero Ruiz de Alarcón (tabla II) - manifiesta la incapacidad de los corregidores para desempeñar eficazmente su oficio, especialmente en aquellos casos en los que las designaciones se suceden en el tiempo y persiguen el mismo objeto insatisfecho, caso de la restitución de las fortalezas de la ciudad o de otros términos entrados por miembros de la nobleza territorial ${ }^{30}$. El estado de guerra civil en estos primeros años no constituyó necesariamente causa suficiente para explicar la limitación —incluso absoluta - de esos resultados. Precisamente, el éxito militar alcanzado por algún capitán real, como Juan Osorio en el sector optense, decidirá a los reyes a promoverle al corregimiento compartido sobre Cuenca y Huete. De hecho, no en todos los concejos se observa una ineficacia similar. Este pudo ser el caso de Madrid, donde, especialmente en la segunda mitad de la centuria, se comprueba un alto grado de aceptación de la presencia de corregidores, debida

29 Así sucede en Jaén, en relación con el alguacil mayor; en Toledo, en 1502, cuando incluso los jurados - representantes del común - ignoran la autoridad del corregidor en beneficio de alguno de los grandes linajes nobles, como los Ayala; o en Segovia, en 1506, en los conflictos por la entrega de la tenencia del alcázar a don Juan Manuel y la violenta oposición mostrada por el marqués de Moya y sus partidarios, que no pudo evitar el corregidor. Véase DIAGO HERNANDO, 2004: 195-223. PRETEL MARÍN, 1978: 191-192. GARCÍA CAÑ́N, 2006: 216-223. RAMOS VÁZQUEZ, 2002: 457-460. LÓPEZ GÓMEZ, 2007: 292-293 y 300303. ASENJO GONZÁLEZ, 1986: 270-272.

${ }^{30}$ Para el caso abulense, MEMBRADO, 2014: 67-84. 
en buena medida al protagonismo asumido por dichos oficiales en la restitución de términos al concejo y en el éxito de sus intervenciones, algo que faltaba en Cuenca $^{31}$.

Cuenca: entre la autonomía política y EL IMPACto de la PRESENCia del CORREGIDOR

La presencia de corregidor en Cuenca es habitual desde comienzos de siglo, aunque nunca llega a adquirir un carácter permanente, en lo temporal, ni sus funciones suponen un estrangulamiento de la autonomía política de la ciudad. Desde esta última perspectiva, cabe afirmar que en la mayoría de las ocasiones el concejo supo oponerse eficazmente al nombramiento/recibimiento del corregidor o supo incorporarlo como un agente más al servicio de los intereses de la ciudad. Hubo excepciones, en las que el corregidor impuso su independencia y autoridad, pero la ciudad se desenvolvió hábilmente en la corte, denunciando los excesos de su conducta y obteniendo su remoción y el envío de un pesquisidor para investigarlo ${ }^{32}$. Desde 1477 en adelante, la designación de corregidor será continua, pero, al menos durante los dos primeros mandatos, que cubren el período aquí examinado, el marco de relación establecido por el concejo con sus corregidores apenas cambia.

\section{La presencia y posición de los corregidores en la ciudad}

En la cronología que nos ocupa, nos consta el corregimiento del bachiller Juan de Paz, cuyo nombramiento se habría efectuado entre el 15 de febrero y el 25 de marzo de 1477, fechas en las que aparece como pesquisidor en tierra de Cuenca y ya actuando como corregidor; y Juan Osorio, cuyo nombramiento se efectúa el 23 de septiembre de 1478, siendo notificado a Cuenca el 6 de octubre de ese año, momento en el que se produjo su recibimiento. El corregimiento de Osorio será prorrogado por anualidades hasta 1483, finalizando el 30 de octubre con el recibimiento del nuevo corregidor, Ruy Gómez de Ayala, por pode-

${ }^{31}$ LOSA CONTRERAS, 1999: 249. En Huete, en el tránsito de la década de 1470 a 1480 , se constata la que parece pacífica coexistencia del corregidor con el guarda mayor Alejo de Sandoval; y lo mismo parece suceder en Murcia en 1480, cuando el adelantado mayor apoya el recibimiento del corregidor. SÁNCHEZ BENITO, 2006: 235-236. JIMÉNEZ ALCÁZAR, 1994, vol. II: 87-96.

32 MOYA PINEDO, 1977, aporta un listado — incompleto - de los corregidores de Cuenca. Sobre la relación del concejo con sus corregidores, véase JARA FUENTE, 2017b: 53-87. 
res dados a su teniente, el bachiller Martín del Castillo ${ }^{33}$. La ausencia de corregidor en los primeros años de reinado no es una nota específica de Cuenca, sino que cabe insertarla en una tendencia más amplia en Castilla, no sólo producto de la decisión de los reyes de servirse de linajes locales poderosos sino de las dificultades experimentadas en un primer momento para hacer valer su autoridad, lo que vendría a justificar aquella opción ${ }^{34}$.

En todo caso, resulta destacable, por un lado, el extraordinariamente corto mandato del bachiller Juan de Paz, que, además, culminaría con su remoción tras la pesquisa encargada a Gerónimo de Valvidieso «sobre los mouimientos, escándalos e ruidos» que habrían tenido lugar en Cuenca y a los que, presumiblemente, el corregidor no habría sabido dar respuesta ${ }^{35}$. Por otro lado, destaca el largo mandato de Juan Osorio, renovado sin la aparente oposición del concejo e, incluso, contando con su buena disposición: cuando, el 5 de julio de 1482, Cuenca escribe a los reyes solicitando que no se designe nuevo corregidor, «por las fatigas de la çibdad e su tierra», el concejo abre la puerta a una designación siempre que recaiga, nuevamente, en Juan Osorio, «por el conosçimiento que de él se ha» ${ }^{36}$. Su aceptación y la justificación de ésta responden a la valoración positiva que hace el concejo de la trayectoria de cooperación llevada adelante por el corregidor durante los años previos. Una trayectoria que reconoció un amplio margen de actuación a la ciudad, y cuyo tono político se inicia con la primera recepción en el oficio, el 6 de octubre de 1478. Aquí, como hemos examinado en otro lugar, se somete el recibimiento del corregidor al juramento de un capitulado que va más allá de las referencias usuales al servicio de los reyes y el respeto de fueros y privilegios de la ciudad ${ }^{37}$; aquel incluye

33 AGS, Cancillería, RSC, leg. 147702-345, fols. 1r-v; leg. 147703-374, fols. 1r-v. AMC, LLAA, leg. 200, exp. 3, fols. 9r-v y 10v-12r; leg. 201, exp. 1, fols. 89r-90r; leg. 201, exp. 3, fols. 21v23r; leg. 204, exp. 3, fol. 155r; leg. 205, exp. 1, fols. 75r-75v.

En abril de 1482, el corregidor, con permiso de los reyes, comunicaba a Cuenca su intención de acudir a la guerra de Granada. El 18 de marzo de 1483, la reina informaba a Cuenca de que había sido hecho prisionero y, el 25 de julio, ante la virtual certidumbre de su fallecimiento en Granada, el concejo solicitaba la revocación del corregimiento, sin éxito. AMC, LLAA, leg. 203, exp. 2, fols. 204r-205v; leg. 205, exp. 2, fols. 26r-v y 78v.

${ }_{34}$ RUFO YSERN, 1991: 55-75.

35 AMC, LLAA, leg. 200, exp. 3, fols. 8v-9r.

En Madrid, en 1478, los reyes se ven también obligados a remover al corregidor Juan de Bovadilla, aunque manteniéndolo como asistente y entregando los oficios de justicia a Alfonso de Heredia, en lo que posiblemente constituyera un pulso de poder con el concejo. LOSA CONTRERAS, 1999: 229.

36 AMC, LLAA, leg. 203, exp. 2, fol. 261v.

Juan Osorio será simultáneamente corregidor de Huete, donde su presencia no resulta tan incontestada, especialmente por el común. SÁNCHEZ BENITO, 2006: 243-244.

37 AMC, LLAA, leg. 200, exp. 3, fols. 9r-v y 10v-12r. Véase JARA FUENTE, 2017b: 53-87.

Sobre estos capitulados, GONZÁLEZ ALONSO, 1970: 50 y 87-88. ORELLA UNZUÉ, 1987: 84-85. 
la preservación del término jurisdiccional, la observación y el cumplimiento de las ordenanzas urbanas, la negativa a recibir oficios acrecentados, y el respeto de la posición de poder del guarda mayor y de los regidores. Además de la importancia de esto último, debe destacarse que, respecto de las ordenanzas, el corregidor jura respetar tanto las ya promulgadas como aquellas que se elaboren en adelante por el guarda mayor y los regidores, sin incorporar referencia alguna a la participación del propio corregidor en dicho proceso; y que la negativa a los oficios acrecentados deberá efectuarse de conformidad con la guarda mayor y regidores, lo que abría la posibilidad de que éstos aceptaran un acrecentamiento, forzando así al corregidor a pasar por él. Se trata de un capitulado que directamente vincula el ejercicio de las funciones corregimentales no sólo a los intereses de la monarquía y la ciudad, sino a los más específicos de las máximas autoridades urbanas. En estas condiciones y habida cuenta de la respuesta positiva dada por Juan Osorio durante sus mandatos, no extraña que, con independencia de las reclamaciones efectuadas por las ciudades - Cortes de Madrigal de 1476 y Valladolid de 1506 - en relación con los mandatos y prórrogas de los corregidores, no resultara conflictiva en Cuenca la continuidad de este oficial ${ }^{38}$. Razones parecidas, vinculadas a la activa y exitosa defensa de su término, llevarán al concejo de Madrid a solicitar la prórroga del corregidor García de la Quadra en 1485, acudiendo a una justificación similar: «Este buen hombre, quien siempre fue justo y mantuvo el orden $\rangle^{39}$.

En todo caso, y en este estadio del proceso de desarrollo de la centralización, el recibimiento del corregidor no implicó necesariamente una transformación profunda de los marcos de intervención política en la ciudad, entre otras razones porque el recibimiento por el concejo no equivale automáticamente a una presencia y participación estable y permanente en los negocios de la ciudad por parte del corregidor. De hecho, si algo destaca en estos primeros años es la relativa presencia efectiva de este oficial, compensada por su delegación en la figura del alcalde mayor, como ilustra la tabla III.

Tabla IIIA. Presencia en las sesiones de ayuntamiento. Período 1478-1479

\begin{tabular}{|c|c|c|c|c|c|c|}
\hline Sesiones & Corregidor & $\begin{array}{c}\text { Alcalde } \\
\text { mayor }\end{array}$ & $\begin{array}{c}\text { Asistencia: } \\
\text { corregidor + } \\
\text { su alcalde (\%) }\end{array}$ & $\begin{array}{c}\text { Guarda } \\
\text { mayor }\end{array}$ & $\begin{array}{c}\text { Teniente } \\
\text { del guarda } \\
\text { mayor }\end{array}$ & $\begin{array}{c}\text { Asistencia: } \\
\text { guarda + su } \\
\text { teniente (\%) }\end{array}$ \\
\hline 46 & 20 & 26 & 100 & 6 & 9 & 32,60 \\
\hline
\end{tabular}

${ }^{38}$ Sobre los problemas planteados por las prórrogas, las reclamaciones en Cortes y la negociación de sus recibimientos, GONZÁLEZ ALONSO, 1970: 94-97. BERMÚDEZ AZNAR, 1974: 139-141. LOSA CONTRERAS, 1999: 233-234. RUFO YSERN, 1991: 55-75. ORELLA UNZUÉ, 1987: 84-85.

${ }^{39}$ LOSA CONTRERAS, 1999: 246. 
TABla IIIв. Presencia en las sesiones de ayuntamiento. Período 1479-1480

\begin{tabular}{|c|c|c|c|c|c|c|}
\hline Sesiones & Corregidor & $\begin{array}{c}\text { Alcalde } \\
\text { mayor }\end{array}$ & $\begin{array}{c}\text { Asistencia: } \\
\text { corregidor }+ \\
\text { su alcalde (\%) }\end{array}$ & $\begin{array}{c}\text { Guarda } \\
\text { mayor }\end{array}$ & $\begin{array}{c}\text { Teniente } \\
\text { del guarda } \\
\text { mayor }\end{array}$ & $\begin{array}{c}\text { Asistencia: } \\
\text { guarda + su } \\
\text { teniente (\%) }\end{array}$ \\
\hline 27 & 6 & 21 & 100 & 1 & 2 & 11,11 \\
\hline
\end{tabular}

Fuentes: AMC, LLAA. Elaboración propia.

Aunque el segundo período se encuentra peor documentado - como delata el número de sesiones recogidas-, se constata el interés del corregidor por asegurar una presencia permanente en el principal espacio de deliberación y toma de decisiones de la ciudad, bien personalmente, bien a través de su alcalde mayor. Sin embargo, si asumimos que el peso político que podía desplegar el segundo podía no ser equivalente al del corregidor, la sustancial diferencia que tiene el impacto de la presencia del corregidor en estas sesiones de un período a otro - prácticamente se reduce a la mitad, pasando de un $43,48 \%$ a un $22,22 \%$ - podría explicarse por una comunicación bien lubricada y una cooperación eficiente entre corregidor y concejo, que haría innecesaria la presencia continua de aquel en la ciudad, máxime si se tiene en cuenta que simultaneaba sus funciones con el corregimiento de la vecina Huete. Paralelamente, se observa una reducción del influjo que el guarda mayor podía ejercer - al menos directamente pues habría que valorar su capacidad, aún significativa, de clientelización de miembros del segmento dominante de la ciudad - en los acuerdos adoptados en dichas sesiones. Si en el período 1474-1476 los reyes habían delegado su autoridad en la ciudad y su territorio en este linaje, y su primacía política se habría prolongado durante el corregimiento del bachiller Juan de Paz, como denota el capitulado que se hizo jurar a Juan Osorio en su primer recibimiento; con la presencia de este corregidor su peso político - institucional cuando menos - comienza a reducirse, y de manera significativa, como ilustran los datos reflejados en la tabla.

\section{La gestión de la autonomía política del concejo}

La presencia del corregidor, o de su teniente - sólo hacia el final del mandato, con la designación del comendador Juan Serrano el 26 de abril de $1482^{40}$ — o alcalde mayor en la totalidad de las sesiones de ayuntamiento

${ }^{40}$ La designación se produjo con ocasión de la marcha de Juan Osorio a la guerra de Granada. AMC, LLAA, leg. 203, exp. 2, fols. 204r-205v. 
celebradas durante el mandato de Juan Osorio, no significa necesariamente que todos los negocios de la ciudad fueran dirigidos por o atendidos en presencia y con la participación del corregidor y/o sus oficiales ${ }^{41}$. Algunos de los actos de gobierno de los regidores tienen lugar fuera del ayuntamiento y no suelen implicar la presencia y participación de aquellos oficiales regios. E, incluso, actos que deben producir sus efectos en dichas sesiones, se hallan dotados de cierta independencia respecto no ya de la participación del corregidor o sus oficiales sino siquiera sea de su presencia pasiva. Esto último es lo que sucede en el ámbito de la comunicación política del concejo con otros sistemas o agencias, en los dos sentidos, como agente emisor y receptor, tal y como se ilustra en la tabla IV.

La información recogida en la tabla nos permite apuntar algunas ideas. En primer lugar, sobre la lógica de los flujos de comunicación. En algunos casos parece razonable que la monarquía se dirija exclusivamente al concejo, como en los relacionados con la prórroga del corregidor y su recibimiento, que legalmente constituía un acto de concejo, al margen de si la prórroga era presentada por el mismo corregidor en activo. Sin embargo, en los demás casos señalados, sorprende la ausencia de este oficial o de sus subordinados en procedimientos que, como mínimo, precisarían del control ejecutivo del corregidor: el respeto de las ordenanzas, la preservación del término jurisdiccional — de vecinos deseosos de erigir dehesas de dudosa legalidad o de señores ansiosos de usurpar términos-, el control de la fiscalidad regia, la designación de oficiales que han de ser confirmados por los monarcas - caso del escribano mayor o del letrado del concejo-; comunicaciones que se suceden a lo largo de los años sin concitar ni siquiera la protesta del corregidor o sus oficiales, lo que indica un alto grado de asimilación de estas prácticas dentro del modelo político-relacional que liga a concejo y corregidor ${ }^{42}$. En segundo lugar, llama la atención la concentración de casos en los años previos a 1480 y su menor presencia con posterioridad. Quizás haya que explicarlo como una consecuencia más de las Cortes de Toledo, que conduciría a un ejercicio del corregimiento más «próximo» a la realidad política local, como refleja la mayor implicación del comendador Juan Serrano, quien supo incorporarse como co-emisor a esos canales de comunicación, en las tareas de gobierno ${ }^{43}$.

${ }^{41}$ Sobre la presencia de estos oficiales en las sesiones de ayuntamiento, PRETEL MARÍN, 1992: 352. RAMOS VÁZQUEZ, 2002: 358-361. LOSA CONTRERAS, 1999: 292-296.

42 Sobre estas funciones, LOSA CONTRERAS, 1999: 240-246 y 297-298. RAMOS VÁZQUEZ, 2002: 142-147 y 499-539.

${ }^{43}$ Así sucede en cartas de 4 de junio, y de 23 y 26 de julio de 1482, a las villas de Torralba y Cañaveras — de Pero Carrillo de Albornoz-, sobre entrada de términos de Cuenca; y en otra, de 12 de julio, a los reyes, sobre el pleito con Lope Vázquez de Acuña por los lugares entrados del Val de Viana. AMC, LLAA, leg. 203, exp. 2, fols. 243r-v, 273v-274r y 275r. 
TABLA IV. Relaciones epistolares «exclusivas» con el concejo de Cuenca (1478-1482)

\begin{tabular}{|c|c|c|c|}
\hline Emisor & Receptor & & Fecha \\
\hline \multirow[t]{7}{*}{ Monarquía } & Concejo & Nombramiento/prórroga de corregidor & $\begin{array}{l}\text { 1478, septiembre, } 23 \\
\text { 1479, agosto, } 30 \\
1480 \text {, julio, } 28 \\
1482 \text {, agosto, } 12\end{array}$ \\
\hline & & Nombramiento de regidor & $\begin{array}{l}1479, \text { noviembre, } 2 \\
1480 \text {, agosto, } 16\end{array}$ \\
\hline & & $\begin{array}{l}\text { Nombramiento de otros oficiales } \\
\text { menores }\end{array}$ & $\begin{array}{l}1480, \text { mayo, } 19 \\
1480, \text { octubre, } 11\end{array}$ \\
\hline & & Ordenación/prórroga de pesquisas & 1478, septiembre, 24 \\
\hline & & $\begin{array}{l}\text { Mandamiento, a petición de los } \\
\text { hombres buenos de Cuenca, para que } \\
\text { el concejo respete sus ordenanzas }\end{array}$ & 1480 , noviembre, 3 \\
\hline & & $\begin{array}{l}\text { Mandamientos en relación con } \\
\text { reclamaciones efectuadas contra el } \\
\text { concejo por vecinos }\end{array}$ & 1478 , septiembre, 23 \\
\hline & & Mandamientos en materia de alcabalas & 1479, mayo, 5 \\
\hline Hermandad & Concejo & $\begin{array}{l}\text { Mandamientos y correspondencia de } \\
\text { la Hermandad }\end{array}$ & $\begin{array}{l}1479, \text { junio, } 18 \\
1482, \text { mayo, } 5\end{array}$ \\
\hline \multirow[t]{4}{*}{ Concejo } & $\begin{array}{l}\text { Monarquía } \\
\text { y nobleza en } \\
\text { rebeldía }\end{array}$ & $\begin{array}{l}\text { Correspondencia dirigida a la nobleza } \\
\text { territorial en rebeldía y a los reyes } \\
\text { (incluye el envío a terceros solicitando } \\
\text { su ayuda) }\end{array}$ & $\begin{array}{l}1479, \text { sm, sd } \\
1479, \text { mayo, } 25 \\
1479, \text { agosto, } 3 \\
1479, \text { septiembre, } 2 \\
\end{array}$ \\
\hline & Monarquía & $\begin{array}{l}\text { Correspondencia en relación con una } \\
\text { dehesa que mosén Diego de Valera } \\
\text { posee ilegalmente }\end{array}$ & 1479, julio, 16 \\
\hline & & $\begin{array}{l}\text { Correspondencia solicitando la } \\
\text { designación de oficiales del concejo, } \\
\text { por fallecimiento de su titular }\end{array}$ & 1480, mayo, 2 \\
\hline & & $\begin{array}{l}\text { Correspondencia sobre la prórroga } \\
\text { del corregimiento }\end{array}$ & 1482 , julio, 5 \\
\hline
\end{tabular}

Fuentes: AMC, LLAA y AGS, Cancillería, RSC. Elaboración propia.

Aunque ni siquiera en este caso conviene exagerar el nivel de inserción de la presencia corregimental en los asuntos urbanos pues durante el mandato del comendador constan otras medidas adoptadas por el concejo contra la usurpación de sus términos, implementadas al margen de la autoridad de aquel oficial ${ }^{44}$.

${ }^{44}$ Caso de los mandatos a los concejos aldeanos, el 1 de junio de 1482, y al de Chumillas, el 12 de junio, ordenando expulsar y prendar los ganados invasores y segar los panes ilegalmente sembrados en su término. AMC, LLAA, leg. 203, exp. 2, fols. 239v y 247r. 
Una autoridad que se iría asentando paulatinamente en la ciudad y que acabaría abarcando el conjunto de la vida política urbana, al menos como agencia pasiva, presencial. El regimiento seguirá encargándose de la gestión cotidiana del concejo: avecindamientos, control del mercado y de los precios, control de los cabildos de la ciudad, declaración de la veda del vino, sorteo de los oficios forales y recepción de los nuevos oficiales, elección de los oficios menores, redacción de ordenanzas, ordenación de libramientos, gestión de las rentas y propios, gestión de los repartimientos y empréstitos, control de las cuentas del mayordomo, ejercicio de la autoridad sobre la jurisdicción, recuperación de lugares entrados, relaciones con los concejos comarcanos y con la nobleza territorial... La vida del concejo y la autoridad del regimiento permanecen, aunque experimentan un cierto grado de intervención, diverso en función del área de proyección de la autonomía urbana y de la cronología abordada. Sin embargo, la sola presencia del corregidor o sus oficiales en las sesiones de ayuntamiento no debe engañar sobre lo que representó efectivamente en cada momento. En estos años, la tendencia observada conduce a relativizar el peso de su presencia en la autonomía política de la ciudad. Apenas constan fricciones entre el concejo - los regidores - y el equipo corregimental y, en los pocos casos en que surgen, los regidores suelen salir exitosos de la confrontación.

Es la experiencia del bachiller Juan de Paz, incapaz de reducir la turbulenta vida política de la ciudad durante su mandato. El 27 de noviembre de 1477, los reyes le recordaban que habían mandado a los vecinos de Cuenca que «non fuesen osados de hacer vnos con otros nin otros con otros confederaçiones nin ligas nin monipodios», y que a él correspondía exigir su cumplimiento. El 6 de febrero de 1478, conociendo por el propio corregidor que las alteraciones continúan y claramente exasperados con su incapacidad, le responden que «quisiéramos que commo pasó luego syn nos más requerir nin consultar, puniérades e castigárades los delinquentes, que para las tales e semejantes cosas proueemos de corregidores $\rangle^{45}$. Tampoco Cuenca saldría malparada del conflicto, que se cerró con la realización de una pesquisa que en la práctica supuso el fin del corregimiento del bachiller de Paz y la llegada de Juan Osorio. No parece que la pesquisa perjudicara al concejo pues consta el interés de la ciudad por su prorrogación, que la reina denegaría ${ }^{46}$.

Lo mismo sucede en otro espacio de gestión de singular relevancia, el control de las cuentas del concejo y, en general, del proceso de gestión de los recursos económicos. La ciudad, sus regidores, supo preservar este espacio de autonomía

45 AGS, Cancillería, RSC, leg. 147711-374, fols. 1r-v; leg. 147802-62, fols. 1r-2r.

${ }^{46}$ La conexión de la pesquisa con el nuevo nombramiento en AGS, Cancillería, RSC, leg. 147809-149, fols. 1r-2r; y la prórroga de la pesquisa en AMC, LLAA, leg. 200, exp. 3, fols. $8 v-9$ r. 
política al menos hasta la finalización del corregimiento de Juan Osorio, en octubre de 1483. Ello incluye, claro está, al bachiller Juan de Paz, a quien la reina había encomendado tomar las cuentas del concejo de los últimos diez años sin éxito, por lo que, el 15 de septiembre de 1477, reiteraría la orden con la amenaza de privación de oficios y confiscación de bienes. No consta que Juan de Paz llegara a tomar las cuentas pues, por un acta de 13 de marzo de 1479, sabemos que la reina había ordenado nuevamente tomarlas al corregidor Juan Osorio y al comendador Pero Suárez del Castillo, vecino de Cuenca, en ambos casos con un salario de $3.000 \mathrm{mrs}$. Los regidores, demostrando cintura política, negociarían con el corregidor la toma de cuentas y la renuncia a su salario, evitando, así, someter esa parte tan sensible del sistema político urbano que controlaban los regidores a la fiscalización de un vecino, integrante del segundo escalón de la clase dominante. Lo contrario habría supuesto invertir la lógica de la dominación. Fernando V ordenaría la anulación de la comisión de Pero Suárez, autorizando al concejo a nombrar a una persona hábil para actuar en compañía del corregidor y con el salario indicado, proporcionando al regimiento no sólo una palanca de control de la toma de cuentas sino también de implementación de sus políticas de clientelización ${ }^{47}$. No se trató de un triunfo del corregidor sino de una victoria del regimiento, pues en los años sucesivos lo vemos controlar con un alto grado de autonomía sus asuntos económicos. Durante el mandato de Juan Osorio, el concejo se presenta como única instancia de ordenación de la política de ingresos y de gastos, tal y como se desprende de sus prácticas de libramiento y rendición y toma de las cuentas del mayordomo. Respecto de los libramientos, constan disposiciones sobre el modo de ejecutarlos, emitidas por los regidores $\sin$ interferencia de los oficiales corregimentales ${ }^{48}$, quedando, pues, bajo el control del regimiento ${ }^{49}$. Un control que se extendió a los repartimientos anuales para pago de la martiniega que satisface la tierra y de los gastos realizados por la ciudad y los concejos aldeanos durante el año previo: el llamado pecho de San Miguel y forero, repartimientos que constituyen, al tiempo, ocasión para tomar las cuentas del mayordomo. Disponemos de los repartimientos de martiniega y

${ }^{47}$ AMC, LLAA, leg. 200, exp. 3, fol. 60v; leg. 201, exp. 1, fols. 90v-91v.

48 Con posterioridad, se producirán enfrentamientos por el control de los libramientos, resueltos por los reyes en carta de 20 de noviembre de 1485, ordenando la aprobación del concepto de pago por regidores y corregidor, pero limitando la firma del libramiento a los regidores. AMC, LLAA, leg. 201, exp. 3, fol. 17v; leg. 203, exp. 2, fol. 197v. AGS, Cancillería, RSC, leg. 148511-31, fols. 1r-2r.

49 Lo que no significa ausencia de presencia o colaboración de la autoridad corregimental. Cuando, el 31 de enero de 1480, se ordena librar el sueldo del diputado de Hermandad mosén Alfonso de Alarcón, vecino de Cuenca, se hace en presencia de los alcalde y alguacil mayores; y cuando, el 16 de marzo de 1482, Cuenca ordena al concejo aldeano de Valera de Suso repartir los maravedíes necesarios para la reparación de un horno, firman el mandato el corregidor y los regidores. AMC, LLAA, leg. 201, exp. 3, fols. 31v-32r; leg. 203, exp. 2, fol. 173r. 
del forero de 1478, 1479, 1480, 1482 y 1483, y sólo en la martiniega de 1480 consta el corregidor Juan Osorio asistiendo al acto; fuera de esa excepción, los mencionados repartimientos se realizan únicamente en presencia de regidores y sexmeros - representantes de la tierra, como es costumbre. Así mismo, consta un repartimiento, en mayo de 1479, del coste del servicio de lanzas de la Hermandad, que habían de sufragar las cuadrillas de la ciudad; y otro, del mismo año, para pago de la milicia que se distribuye por la jurisdicción, y que habían de sufragar los concejos aldeanos. Ambos se efectuaron solamente en presencia de los regidores y de los cuadrilleros, el primero, y sexmeros, el segundo, como establecía la norma ${ }^{50}$. Es posible que similares niveles de cooperación y autonomía se alcanzaran en otros concejos, como sucede en Madrid al menos con la política de libramientos ${ }^{51}$.

En todo caso, lo que demuestra el examen de estos espacios de acción política es el grado de imbricación, cooperación y respeto mutuo que representó la relación establecida por los corregidores y sus oficiales con las autoridades urbanas y singularmente los regidores; ello, al menos, en los primeros años del reinado de Isabel I, incluyendo los que pivotan alrededor de las Cortes de Toledo de $1480^{52}$. La presencia de estos oficiales no supuso, en esta cronología, un verdadero recorte de las funciones y poder de los regidores. La iniciativa y energía política mostradas por éstos en la defensa de los intereses urbanos, en cooperación o con independencia del guarda mayor —entre 1474 y 1476-77_ y del corregidor — desde 1477 hasta finales de 1483 - , como muestran no sólo las acciones emprendidas sino el uso de los canales de comunicación examinados, situaban al regimiento en la primera línea del proceso político-decisional. En este contexto, el desigual desempeño de las funciones corregimentales, especialmente en el ámbito de protección de la jurisdicción de la ciudad y de restitución de sus términos, reducía su capacidad de competición con la autoridad urbana ${ }^{53}$. De hecho, el 26 de abril de 1482, Juan Osorio, en cumplimiento de cartas de los reyes,

50 AMC, LLAA, leg. 200, exp. 3, fols. 58r-59v, 15v-19v y 20r-31v; leg. 201, exp. 1, fols. 100r-101v; leg. 201, exp. 2, fols. 107v-111v y 112r-132v; leg. 201, exp. 3, fols. 1r-v; leg. 204, exp. 1, fols. $57 \mathrm{v}-63 \mathrm{r}$ y $64 \mathrm{r}-76 \mathrm{v}$; leg. 205 , exp. 1, fols. $38 \mathrm{r}-40 \mathrm{v}$, $43 \mathrm{r}-65 \mathrm{v}$ y $86 \mathrm{v}-87 \mathrm{v}$.

${ }^{51}$ En general, el nivel de control ejercido por los corregidores parece mayor que en Cuenca, aunque esta imagen puede deberse a que estos estudios se centran en períodos posteriores a 1480, o a una menor riqueza de las fuentes. LOSA CONTRERAS, 1999: 314 y 422-423. RAMOS VÁZQUEZ, 2002: 644-647. MENJOT, 1986: 30-31. SÁNCHEZ BENITO, 2006: 260-261. GAUTIER DALCHE, 1985: 507-520.

${ }^{52}$ No en todos los concejos sucedería así, constituyendo 1480 un giro hacia un mayor nivel de injerencia. PRETEL MARÍN, 1989: 50.

${ }_{53}$ Parte de esta incapacidad estaría causada por las reticencias de estos oficiales para intervenir en contra de señores poderosos, o las connivencias mostradas con ellos. LUNENFELD, 1987: 111-112. QUINTANILLA RASO, 1997a, vol. I: 707-736. RAMOS VÁZQUEZ, 2002: 238-240. Para este área, SÁNCHEZ BENITO, 2014: 463-501; 1996: 89-118. 
ordenaba al concejo juntarse con el comendador Juan Serrano para ejecutar las sentencias de términos dictadas por el doctor de Briviesca ${ }^{54}$. Pero Sánchez de Frías las había otorgado en 1477 y cuatro años y medio después seguían sin cumplirse o lo establecido en ellas había dejado de observarse por la nobleza comarcana y sus concejos aldeanos. Las acciones emprendidas se zanjaron con cierto éxito, aunque en todos los casos ello implicó el despliegue de los caballeros de la sierra —oficiales forales de la ciudady/o la milicia del concejo. La focalización de los procesos de recuperación en torno a la visualización del vecindario de ciudad y tierra asumiendo el protagonismo de aquellos mandatos, sin duda restaría una parte de sus réditos políticos al teniente de corregidor, que debería compartir con el concejo, es decir, con los regidores ${ }^{55}$. De esta manera, el protagonismo que podía alcanzar el oficial corregimental se veía necesariamente limitado por su incapacidad para actuar sin contar con el apoyo directo del regimiento. Así, el mandato dirigido por Fernando V, el 27 de mayo de 1482, a Álvaro de Alarcón, comendador de Uclés, reiterándole la orden de derribar la fortaleza que había comenzado a construir en término de Almodóvar del Pinar, aldea de Cuenca, reconocía en la práctica dichas limitaciones: el comendador de Uclés había acordado paralizar las obras hasta recibir noticia de los reyes, lo que había negociado con el concejo y el corregidor; y la información, protestando por las acciones de aquel, había sido llevada a los monarcas por Fernando de Albornoz, regidor de Cuenca ${ }^{56}$.

La ocupación del primer plano de la acción política —al menos en cuanto a la imagen que de ella se generaba- estaba firmemente ocupada por el regimiento, y los oficiales corregimentales podían aspirar a compartirla de una manera no siempre equilibrada para ellos. Al menos esa era la percepción extendida en la ciudad, como ilustran las treguas y seguros ofrecidos por el marqués de Villena a Cuenca entre los meses de mayo y agosto de 1479. Si el 21 de mayo, el marqués se dirige al «conçejo, corregidor, justiçia, regidores, caualleros, escuderos, ofiçiales e omnes buenos de la muy noble çibdat de Cuenca»; el 25 de mayo le respondía el «conçejo, justiçia, regidores, caualleros, escuderos, ofiçiales e omnes buenos de la muy noble e leal çibdat de Cuenca», sin incorporar expresamente en la cláusula de emisor al corregidor o sus oficiales, a quienes tampoco incorporaron expresamente a la carta enviada ese día a

54 AMC, LLAA, leg. 203, exp. 2, fol. 205v.

La inoperancia del corregidor se acompasa con la desplegada por los reyes pues, como lamenta Cuenca, el 12 de julio de 1482, el pleito que sostiene con Lope Vázquez de Acuña por los términos del Val de Viana seguía pendiente de resolución en el Consejo. AMC, LLAA, leg. 203, exp. 2, fols. $269 \mathrm{v}-270$ r.

55 JARA FUENTE, 2007: 143-170.

${ }_{56}$ AMC, LLAA, leg. 203, exp. 2, fols. 245r-246v. 
los reyes sobre las treguas. Más adelante, el 12 de agosto, en presencia del alcalde y alguacil mayores, escribían al marqués otorgándole seguro en las mismas condiciones que él les había ofrecido por intermedio de Pero Suárez de Toledo, vecino de Cuenca y miembro de uno de los principales linajes de la ciudad - Álvarez de Toledo-, quien había sido enviado a negociar con don Diego López Pacheco. El seguro se otorgó tras un largo debate en la sesión de ayuntamiento de aquel día, cuya importancia condujo al escribano a reflejar por extenso las diferentes opiniones vertidas, indicando sólo en algún caso el nombre de quien intervenía, no recogiéndose intervenciones del alcalde ni del alguacil mayor, aunque pudieron producirse. La sesión se reanudaría en dos ocasiones, tomando en la primera la palabra cuatro regidores y otros vecinos para mostrar su voluntad de servir a los reyes si se decidía no aceptar la tregua; y haciéndolo en la segunda el procurador síndico, Sancho Platero, conformándose con lo que decidieran

... el alcalde que está en lugar del rey e reyna, nuestros sennores, por justiçia y desea su seruiçio e el bien desta çibdat e su tierra e es letrado, y eso mesmo ay está el bachiller Gonçalo Sanches de Oliuares, que es letrado de la dicha çibdat, e esos sennores regidores que son personas discretas e aman e desean el seruiçio del rey e reyna, nuestros sennores, e de la dicha çibdat e su tierra e son gouernadores della ${ }^{57}$.

Como ilustran estas treguas y seguros, el regimiento había demostrado su capacidad para transformar su institución en el interlocutor válido del marqués y de los reyes, según refleja la dirección de las negociaciones — asumida por un vecino de la ciudad, integrante de uno de sus linajes regimentales más importantes - y la absorción del proceso de comunicación epistolar; todo lo cual dejaba en segundo plano a los agentes corregimentales. La imagen de la relación de poderes entre regimiento y corregimiento que ello contribuía a generar, aparece magníficamente ilustrada en la intervención del procurador síndico y en el uso que hace de los respectivos referentes de identidad política: en el caso del alcalde mayor — no se mencionó al alguacil, también presente-, esos rasgos específicos se reducían a las funciones de justicia pues el servicio a los reyes lo compartía con los regidores y su condición de letrado, con el de la ciudad; en el caso de los regidores, Sancho Platero construyó un entramado de identidad política más completo, complejo y centrado en la definición de la superior autoridad urbana que ostentan en su condición de «gouernadores della». La primacía de los regidores no se discutía, no al menos en este período.

${ }^{57}$ AMC, LLAA, leg. 201, exp. 1, fols. 53r-54r, 56v-57v y 70v (la cita, en el último folio). 


\section{Conclusiones}

La inserción de la agencia corregimental en las ciudades castellanas no debería ser considerada como expresión de una proyección automática de la centralización política impulsada - y no resuelta, al menos en términos absolutos- por los Reyes Católicos. Durante los años de la contienda sucesoria, los corregidores no constituyeron el instrumento principal de intervención de la monarquía en los espacios sujetos o no a la contienda, pues los reyes optaron por aplicar una política realista, basada en el reconocimiento de los poderes locales —urbanos o nobles - allí donde podían ser incorporados a su partido. En esos años e incluso en el período transicional que se abre tras las Cortes de Toledo de 1480, los corregidores tampoco alcanzaron a desplegar su potencial. La pacificación del reino contribuyó a generar una nueva percepción de orden y seguridad de la que se pudo beneficiar el corregidor, pero en buena medida aquella descansó, en el nivel local, en la acción de las milicias concejiles y en las elites de los concejos, lo que, en ciudades como Cuenca, dejaba poco reconocimiento para el corregidor. En muchos casos, éste tampoco fue capaz de beneficiarse del estado de paz para emprender una eficaz política de restitución de términos ${ }^{58}$.

El estudio ilustra dos cuestiones importantes. Primero, la necesidad de acudir al examen práctico de las relaciones políticas tejidas en cada momento por las agencias urbana y corregimental, y sus conexiones con otras agencias. El examen frío de la normativa sobre las funciones del corregidor y sus agentes resulta insuficiente para considerar la realidad de la imbricación de esta figura en el sistema urbano. Sólo el análisis del modo en el que, en la práctica cotidiana del poder en ese nivel local, se organizan los procesos de relación política indica el peso relativo real de cada agencia.

En segundo lugar, el estudio examina la posición efectivamente ocupada por el corregidor en la ciudad, concluyendo en un posicionamiento limitadamente competitivo con la autoridad urbana y otros actores. En los primeros años de guerra civil sucesoria, el corregimiento no fue necesariamente la primera opción en las políticas de centralización, pues la monarquía optó por apoyarse en algunos lugares en linajes locales de potentes. Cuando por fin se opta por la vía del corregimiento, este oficial ha de consolidar su posición y el ejercicio de su poder en un marco en el que compite con otros agentes regios capitanes, pesquisidores, ejecutores- que le suponen límites funcionales, y con los miembros de la nobleza territorial, deseosos de preservar y aún continuar con sus usurpaciones en el realengo. Además, como demuestra el caso de Cuenca, la superioridad de la autoridad corregimental precisó de una implantación progresiva, incorporándose como colaborador de la agencia regimental

58 MONSALVO ANTÓN, 2010b: 253-319. SÁNCHEZ BENITO, 2006: 118-119. 
$\mathrm{y}$, paulatinamente, asumiendo un protagonismo que no restaba reconocimiento a la realidad del poder, fuertemente articulado y cohesivo, ejercido por los regidores. En la cronología examinada, en Cuenca, el corregidor y sus oficiales no representaron una centralización opresiva - limitadora - para las autoridades locales.

\section{Bibliografía}

Asenjo González, María, Segovia. La ciudad y su tierra a fines del medievo, Segovia, Diputación Provincial, 1986.

Asenjo González, María, «Función pacificadora y judicial de los corregidores en las villas y ciudades castellanas, a fines de la Edad Media», Medievalista online [en línea], 18 (2015), disponible https://medievalista.iem.fcsh.unl.pt/index.php/ medievalista/article/view/198/184 (consultado en julio de 2021).

Bermúdez Aznar, Agustín, El corregidor en Castilla durante la Baja Edad Media (1348-1474), Murcia, Universidad de Murcia, 1974.

Carrasco Manchado, Ana Isabel, «Entre el rey y el reino calladamente está fecho un contrato. Fundamentos contractuales de la monarquía trastámara en Castilla en el siglo XV», en François Foronda, Jean-Philippe Genet, José Manuel Nieto Soria (dirs.), Avant le contrat social : le contrat politique dans l'Occident médiéval, XIIIe-XVe siècle, París, Publications de la Sorbonne, 2011: 613-652.

Cortes de los antiguos reinos de León y de Castilla, Madrid, Real Academia de la Historia, Imprenta de M. Ribadeneyra, 1866, vol. III.

Diago Hernando, Máximo, Soria en la Baja Edad Media. Espacio rural y economía agraria, Madrid, Editorial Complutense, 1993.

Diago Hernando, Máximo, «El papel de los corregidores en los conflictos políticos en las ciudades castellanas a comienzos del siglo XVI», En la España Medieval, 27 (Madrid, 2004): 195-223.

García Cañón, Pablo, Concejos y señores. Historia de una lucha en la Montaña Occidental leonesa a fines de la Edad Media, León, Universidad de León, 2006.

Gautier Dalché, Jean, «Les processus de décision dans un gouvernement urbain selon les Ordonnaces d'Avila (1487)», En la España Medieval, 6 (Madrid, 1985): 507-520.

González Alonso, Benjamín, El corregidor castellano (1348-1808), Madrid, Instituto de Estudios Administrativos, 1970.

Guerrero Navarrete, Yolanda, «La política de nombramiento de corregidores en el siglo XV: entre la estrategia regia y la oposición ciudadana», Anales de la Universidad de Alicante. Historia Medieval, 10 (Alicante, 1994-1995): 99-124.

Guerrero Navarrete, Yolanda, «Orden público y corregidor en Burgos (siglo XV)», Anales de la Universidad de Alicante. Historia Medieval, 13 (Alicante, 20002002): 59-102.

Guerrero Navarrete, Yolanda y Sánchez Benito, José María, Cuenca en la Baja Edad Media: Un sistema de poder, Cuenca, Diputación de Cuenca, 1994. 
Jara Fuente, José Antonio, «The Importance of Being Earnest: Urban Elites and the Distribution of Power in Castilian Towns in the Late Middle Ages», en Isabel Alfonso Antón, Hugh Kennedy y Julio Escalona Monge (eds.), Building Legitimacy. Political Discourses and Forms of Legitimation in Medieval Societies, Leiden / Boston, Brill, 2004: 139-175.

Jara Fuente, José Antonio, «Facing the depredations and fighting the predators. Urban Castile and the defence of municipal jurisdiction in the Late Middle Ages», Imago Temporis. Medium Aevum, 1 (Lérida, 2007): 143-170.

Jara Fuente, José Antonio, «Seigneurial Pressure: External Constrictions and Stimuli in the Construction of Urban Collective Identities in Fifteenth-Century Castile», Imago Temporis. Medium Aevum, 10 (Lérida, 2016): 267-289.

Jara Fuente, José Antonio, «La ciudad frente a la agresión noble: el coste del conflicto. Cuenca en el siglo XV», en José Antonio Jara Fuente (coord.), Discurso político y relaciones de poder. Ciudad, nobleza y monarquía en la Baja Edad Media, Madrid, Dykinson, 2017a: 327-370.

Jara Fuente, José Antonio, «Entre el conflicto y la cooperación: la ciudad castellana y los corregidores, praxis de una relación política hasta la monarquía isabelina», Studia Historica. Historia Moderna, 39/1 (Salamanca, 2017b): 53-87.

Jara Fuente, José Antonio, «Más por fuerça que de grado: La acción y el lenguaje de la competencia ciudad-nobleza en la Sierra castellano-manchega, en el advenimiento de la monarquía isabelina», Edad Media. Revista de Historia, 19 (Valladolid, 2018): 114-147.

Jiménez Alcázar, Juan Francisco, «Corregidores y poder municipal: Lorca, 14751516», en Jesús Pradells Nadal y José Ramón Hinojosa Montalvo (coords.), 1490: en el umbral de la modernidad: el Mediterráneo europeo y las ciudades en el tránsito de los siglos XV-XVI, Valencia, Generalitat Valenciana, 1994, vol. II: 87-96.

López Gómez, Óscar, La sociedad amenazada. Crimen, delincuencia y poder en Toledo a finales del siglo XV, Toledo, Ayuntamiento de Toledo, 2007.

López Villalba, José Miguel, «El concejo imparte justicia: cotos de los oficiales locales a mediados del siglo XV», Espacio, Tiempo y Forma, Serie III, Historia Medieval, 22 (Madrid, 2009): 153-184.

Losa Contreras, Carmen, El concejo de Madrid en el tránsito de la Edad Media a la Edad Moderna, Madrid, Dykinson, 1999.

Lunenfeld, Martin, Keepers of the City. The Corregidores of Isabella I of Castile (1474-1504), Cambridge, Cambridge University Press, 1987.

Membrado, Sofía, «Los corregidores en los pleitos por la tierra y otros conflictos abulenses: apuntes sobre las cualidades del oficio (1475-1500)», Anuario del Centro de Estudios Históricos «Prof. Carlos S. A. Segreti», 14 (Córdoba, Argentina, 2014): 67-84.

Menjot, Denis, Fiscalidad y sociedad. Los murcianos y el impuesto en la Baja Edad Media, Murcia, Academia Alfonso X el Sabio, 1986.

Monsalvo Antón, José María, «Poder político y aparatos de Estado en la Castilla bajomedieval. Consideraciones sobre su problemática», Studia Historica. Historia Medieval, IV (Salamanca, 1986): 101-167. 
Monsalvo Antón, José María, «Usurpaciones de comunales: conflicto social y disputa legal (culturas políticas, lucha del común y sistema concejil en Ávila y su tierra durante la Baja Edad Media)», en José María Monsalvo Antón, Comunalismo concejil abulense. Paisajes agrarios, conflictos y percepciones del espacio rural en la Tierra de Ávila y otros concejos medievales, Ávila, Diputación Provincial de Ávila / Institución Gran Duque de Alba, 2010a: 115-190.

Monsalvo Antón, José María, «Costumbres y comunales en la tierra medieval de Ávila (observaciones sobre los ámbitos del pastoreo y los argumentos rurales en los conflictos de términos», en José María Monsalvo Antón, Comunalismo concejil abulense. Paisajes agrarios, conflictos y percepciones del espacio rural en la Tierra de Ávila y otros concejos medievales, Ávila, Diputación Provincial de Ávila / Institución Gran Duque de Alba, 2010b: 253-319.

Morán Martín, Remedios, «Alteza... merçenario soys. Intentos de ruptura institucional en las Cortes de León y Castilla», en François Foronda, Jean-Philippe Genet y José Manuel Nieto Soria (dirs.), Coups d'État à la fin du Moyen Âge? : aux fondements du pouvoir politique en Europe occidentale, Madrid, Casa de Velázquez, 2005: 93-114.

Moya Pinedo, Jesús, Corregidores y regidores de la ciudad de Cuenca desde 1400 a 1850, Cuenca, edición privada, 1977.

Nieto Soria, José Manuel, «Rex inutilis y tiranía en el debate político de la Castilla bajomedieval», en François Foronda, Jean-Philippe Genet y José Manuel Nieto Soria (dirs.), Coups d'État à la fin du Moyen Age? : aux fondements du pouvoir politique en Europe occidentale, Madrid, Casa de Velázquez, 2005: 73-92.

Nieto Soria, José Manuel, El conflicto como representación: expresiones de la cultura política Trastámara», en José Manuel Nieto Soria (dir.), El conflicto en escenas. La pugna política como representación en la Castilla bajomedieval, Madrid, Sílex, 2010: $15-55$.

Orella Unzué, José Luis, El delegado del Gobierno Central en Guipúzcoa: estudio histórico-jurídico del corregidor guipuzcoano durante el reinado de Isabel la Católica (1474-1504), San Sebastián, Universidad de Deusto, 1987.

Ortega Cervigón, José Ignacio, «Por seruiçios muchos e buenos que me ha fecho. Los criados de las casas nobiliarias conquenses en la Baja Edad Media», Anuario de Estudios Medievales, 39/2 (Barcelona, 2009): 703-721.

Pérez Priego, Miguel Ángel, «Noticias sobre Alonso Ramírez de Villaescusa, su Espejo de corregidores y el Directorio de príncipes», en José Manuel Lucía Megías (ed.), Actas del VI congreso internacional de la Asociación Hispánica de Literatura Medieval, Alcalá de Henares, Universidad de Alcalá de Henares, 1997, vol. II: 1169-1178.

Pretel Marín, Aurelio, Una ciudad castellana en los siglos XIV y XV (Alcaraz, 13001475), Albacete, Instituto de Estudios Albacetenses, 1978.

Pretel Marín, Aurelio, La «comunidad y república» de Chinchilla (1488-1520). Evolución de un modelo de organización de la oposición popular al poder patricio, Albacete, Instituto de Estudios Albacetenses / Consejo Superior de Investigaciones Científicas, 1989. 
Pretel Marín, Aurelio, Chinchilla medieval, Albacete, Instituto de Estudios Albacetenses / Consejo Superior de Investigaciones Científicas, 1992.

Quintanilla Raso, María Concepción, «Estructuras y relaciones de poder en la tierra de Cuenca a fines de la Edad Media», en Actas de las III Jornadas Hispano-Portuguesas de Historia Medieval, La Península Ibérica en la Era de los Descubrimientos (1391-1492), Sevilla, del 25 al 30 de Noviembre de 1991, Sevilla, 1997a, vol. I: 707-736.

Quintanilla Raso, María Concepción, «La implantación de la nobleza y relaciones de poder en la tierra de Cuenca en la Baja Edad Media», en Joaquín Saúl García Marchante y Ángel Luis López Villaverde (coords.), Relaciones de poder en Castilla: el ejemplo de Cuenca, Cuenca, Universidad de Castilla-La Mancha, 1997b: 103-132.

Ramos Vázquez, Isabel, El concejo de Jaén (1474-1556), Jaén, Universidad de Jaén / Ayuntamiento de Jaén, 2002.

Rufo Ysern, Paulina, «Extensión del régimen de corregidores en Andalucía en los primeros años del reinado de los Reyes Católicos», en Actas del VI Coloquio Internacional de Historia Medieval de Andalucía, Las ciudades andaluzas (siglos XIII-XVI), Málaga, Universidad de Málaga, 1991: 55-75.

Sánchez Benito, José María, «Territorio y conflicto en el ámbito jurisdiccional de Cuenca (época de los Reyes Católicos)», Espacio, Tiempo y Forma. Historia Medieval, 9 (Madrid, 1996): 89-118.

Sánchez Benito, José María, Ciudad, territorio y poder. Huete y sus aldeas en el siglo $X V$, Cuenca, Editorial Alfonsípolis, 2006.

Sánchez Benito, José María, «Nobleza territorial y política ciudadana en el siglo XV (los concejos del área del Tajo)», Espacio, Tiempo y Forma. Serie III. Historia Medieval, 27 (Madrid, 2014): 463-501.

Sánchez Benito, José María, «Bandas armadas en los campos de la Corona de Castilla (siglos XIII-XV)», Vínculos de Historia, 5 (Ciudad Real, 2016): 54-71.

Recibido: $31 / 05 / 2020$

Aceptado: 10/04/2021 
